\title{
The Ambitious Insulator: Revisiting Turkey's Position in Regional Security Complex Theory
}

\author{
ANDRÉ BARRINHA \\ Centre for Social Studies, University of Coimbra, Coimbra, Portugal
}

ABSTRACT According to the Copenhagen School's Regional Security Complex Theory (RSCT), Turkey is an insulator state as it sits at the intersection of different security complexes without truly being part of any of them. This understanding of Turkey's position in the international security realm has offered a welcome contribution to the eternal debate about the country's security alignment between East and West. Turkey has, in recent years, become more active on the international stage, diversifying its relations and taking a more assertive stance regarding international security issues. This shift in its foreign and security policy is related to the country's ambition to become a great power in the near future. However, according to RSCT, it is quite improbable for there to be an insulator state that is also a great power. This article elaborates on the tension between this theory and Turkey's ambitions in an attempt to understand whether and how RSCT remains a useful theoretical framework for the understanding of Turkey's foreign and security relations.

\section{Introduction}

Turkey's foreign and security policy ${ }^{1}$ has, in recent years, undergone considerable changes in terms of both its regional scope and strategic priorities (Yilmaz, 2010: 69). Its active role in international relations is paralleled by its economic growth (in 2011 it achieved real Gross Domestic Product growth of 8.5 per cent, according to The Economist, 2012), as well as by some profound socio-political changes promoted by the Justice and Development Party (AKP) since coming into power in November 2002 (Kirişçi et al., 2010: 11). As a consequence, Turkey is, in the words of former US secretary of state Hillary Clinton, an 'emerging global power', together with China, India, Russia, Brazil, Indonesia and South Africa (quoted in Today's Zaman, 2009a).

Correspondence Address: André Barrinha, Visiting Assistant Professor in International Relations and Researcher at the Centre for Social Studies, University of Coimbra, Rua Jose Alberto Reis 140, 2D, 3000-232 Coimbra, Portugal. Email: abarrinha@ces.uc.pt 
Turkey's goals of being one of the ten largest economies in the world by 2023 (Davutoğlu quoted in Kardaş, 2010: 128), the second largest European economy by 2050 (The Economist, 2012), and a great power in the international system in a few decades have given a strategic direction to Ankara's international activity. However, as this article argues, Turkey's path towards a more visible international status remains hampered by the security dynamics of its regional context. According to the Copenhagen School (CS)'s Regional Security Complex Theory (RSCT), Turkey is an 'insulator', that is, a 'location occupied by one or more units where larger regional security dynamics stand back to back' (Buzan and Wæver, 2003: 41). RSCT structures international relations in accordance with the power and security discourses of its constituent units (which are mostly states, though they may also be sub-national and intergovernmental institutions), in obedience to its realist (material) and constructivist (ideational) roots (ibid.: 4). These complexes are defined by 'durable patterns of amity and enmity taking the form of subglobal, geographically coherent patterns of security interdependence' (ibid.: 45).

Within this context, insulators are distinguished from buffer states in that the latter's function 'is defined by standing at the centre of a strong pattern of securitisation, not at its edge' (ibid.). This means that, despite its strategic relevance, historical past and military power, Turkey sits at the margins of three regional security complexes (RSCs): the European (which includes the Balkans subcomplex); the Middle Eastern (including the sub-complexes of the Levant, Gulf and Maghreb); and the ex-Soviet (including the Baltic; Belarus, Ukraine and Moldova; the Caucasus; and Central Asia) (see Kazan, 2003: 90-91). Even though Turkey participates actively in all three, it does so, according to the CS, from the position of an outsider. By considering Turkey as an insulator, RSCT has been able to convincingly explain why such a relevant geopolitical actor has not been more present in the security dynamics of its neighbours, highlighting Turkey's unique position in the vicinity.

When transposing the theory to Turkey's current foreign and security policy, it becomes clear that RSCT has inadvertently imposed a limitation on its own explanation of this country's recent ascendancy in the international system. The theory states that Turkey can only be promoted to great or superpower status if it first becomes a regional power, and for that to happen it needs to belong to a RSC. For this, it would have to intensify its security relations (of either amity or enmity) with one of the RSCs around its borders, shifting its positioning from a peripheral security role to a central one. In an article published in this same journal a few years ago, Thomas Diez argued that unless Turkey withdrew its EU candidacy or was rejected by Brussels, it was 'increasingly problematic to not view Turkey as a member of the European Security Complex' (2005: 173). However, the intensification ${ }^{2}$ of Turkey's relations with its neighbours (and beyond), combined with its increasing fatigue with the EU accession process in recent years, ${ }^{3}$ has made this claim more questionable in 2013 than it was in 2005 . There has clearly been an intensification of Turkey's regional presence, but this has not been limited to a particular region, at least not sufficiently to consider Turkey's shift to a specific RSC. 
This article discusses whether it is possible for Turkey to become an international power while remaining an insulator state. Even though RSCT, as elaborated by Buzan and Wæver (2003), dismisses such a possibility, it will be argued that, by redefining the relation between the condition of insulator and great power status, it is possible to retain RSCT's analytical value regarding Turkey's international ambitions; that is to say, it may ultimately be possible for there to be a great power insulator.

This article is arranged as follows. It starts by briefly explaining the structure of the international system according to RSCT. Two points are developed in this section: first, the articulation between super-, great and regional powers and, second, the role played by the 'insulator' in the theory. It will be argued that such a role is unnecessarily conditioned by a power typology that lacks consistency and, therefore, explanatory power when applied to cases such as Turkey's. The second part provides a brief overview of Turkey's foreign and security policies since the end of World War I and how these might be explained by RSCT. Particular attention will be paid to the main changes that have taken place in Turkey's foreign policy since the rise to power of the AKP in November 2002. Those changes are shown to be linked to the more general goal of turning Turkey into a great power in the medium to long term, while the Arab Spring has, to an extent, evinced the limitations of Turkey's ambitions. The article will then conclude with an analysis of the insights that this modified version of RSCT can give into Turkey's aspiring foreign and security policy goals.

\section{Regional Security Complex Theory and the Power Structure of the International System}

According to RSCT, the international system is structured around a power spectrum that ranges from superpowers (at the top) to regional powers (at the bottom). More precisely, Buzan and Wæver (2003: 34-35) distinguish between superpowers, great powers ${ }^{4}$ and regional powers. Superpowers are actors with the most far-reaching military, political and economic capabilities. Their actions and policies have a global reach, influencing or determining securitization and desecuritization processes in all or most regions of the international system. The US is currently the only superpower. For the CS, great powers have neither the same global reach nor the same capabilities as superpowers. Nonetheless, a great power is 'treated in the calculations of other major powers as if it has the clear economic, military, and political potential to bid for superpower status in the short or medium term' (Buzan \& Wæver, 2003: 35). Since the end of the Cold War, Britain/France/Germany-EU, Japan, China and Russia are, according to these authors, the current great powers of the international system (ibid.: 36). Together with the lone superpower they constitute the restricted group of global powers whose scope and relevance cuts across regions and issues.

In that regard, global powers are qualitatively different from regional powers, actors with considerable reach at regional level, but very limited capabilities and capacity for action at global level. In regional terms, they define the polarity of RSCs 
such as India or Brazil (ibid.: 37). Regional powers are thus third-tier powers, whose power and ambitions are limited to the RSCs in which they are located. As the authors recognize, they are not structurally part of the international security equation (ibid.: 34).

\section{What Makes a Great Power Great?}

For Buzan and Wæver (2003: 32), in order to classify an international actor as a great power, it is necessary to consider its material capability (military and economic), whether or not it is formally recognized as such by the other main international powers, and how it is incorporated, in practice, into the actors' strategies and behaviours at the systemic (global) level. Moreover, according to these authors, great powers

will generally think of themselves as more than regional powers, and possibly as prospective superpowers, and they will usually be capable of operating in more than one region. But, while these characteristics will be typical of great powers, they are not strictly speaking necessary so long as other powers treat them as potential superpowers. (Ibid.: 35)

Thus, as mentioned above, the key aspect here is not the actor's capability, but rather the formal and practical recognition by its peers of its status as a potential superpower. There is an international intersubjective process in which states are given the respective label of super- or great power, mainly based on the perception of its peers. India is given as an example of a country that does not fulfil the criteria for great power status. Despite its size, economic growth rate and military power (particularly its nuclear arsenal), India's status is inferior to that of Japan, for instance. According to Buzan and Wæver, India does not qualify as a great power because the other powers do not consider it to be a potential superpower (ibid.: 37 ).

A first problem with this idea has to do with the lack of consideration given to the actor's discourse on itself. As argued by Andrew Hurrell (2006: 2), this has to do with the relation between aspiration and capabilities, in which the former can sometimes be a capability in its own right:

[China, India, Brazil and Russia] share a belief in their entitlement to a more influential role in world affairs. Aspiration alone, of course, is not enough ... And yet power in international relations requires a purpose and a project, and the cultivation of such a purpose can both galvanize national support and cohesion at home and serve as a power resource in its own right.

Even though the ultimate decision is taken by its peers, it is important to understand how an actor defines itself, as it may serve, as Andrew Hurrell points out, as a 'power resource in its own right'. This is something that the CS authors do recognize when they state 'China has demonstrated an impressive ability over nearly a century to trade on future capabilities' (Buzan and Wæver, 2003: 35). It could thus be 
understood as somewhat paradoxical that the CS authors overview this aspect in their theoretical construction, placing the burden of decision on the other international actors.

A second, arguably more important, problem has to do with the limited role given to the RSCs in the construction of such criteria. In a work that makes the regional dimension into the key (temporary ${ }^{5}$ ) prism through which to understand international security, it is odd that the criteria for global power status gives very little importance to the quantitative (number) and qualitative (depth) of impact these powers have on distinct RSCs, rather than placing the burden on the potential of horizontal peer recognition. This is particularly surprising given that the CS authors do include regional impact in their distinction between super- and great powers, when they say that the former 'must be active players in processes of securitisation and desecuritisation in all, or nearly all, of the regions in the system' whereas the latter 'need not be actively present in the securitisation processes of all areas of the international system' (ibid.: 35).

This article argues that the articulation between powers and regions would be clearer and the categorization of those different powers more coherent if the focus was placed on the RSCs, as it is in the rest of the theory. In that sense, a great power would not necessarily be defined by its claim to superpower status, but rather by its spatial performance. A state with important influence on diverse RSCs at the same time - an influence based on its actions, discourses and material power - should be considered by the theory as a great power even if it falls short of superpower status.

\section{Insulators and Polarity}

A further problem with the theory has to do with the role attributed to insulators as they are placed outside RSCT's power equation. For an insulator to become a great or superpower it would have to first become a regional power within a RSC, as Buzan and Wæver (2003: 395) conclude when analysing the Turkish case. According to them,

[i]f a much-strengthened Turkey actually becomes the regional great power it claims it is, it could trigger such a coalescence of its neighbours; it would then increasingly have to be analysed as a pole in some RSC, not only as insulator between RSCs.

In order to solve a problem that seems unnecessary in the light of the coherence of the overall theory, this article proposes a second conceptual change based on the assumption that there is no necessary linkage between a regional and great power. A regional power is not necessarily a third-tier power at the international level: it can, following the theory, be understood as a regional first-tier power. This means that, unlike great and superpower status, both of which may be understood as absolute conditions, a regional power is a relative condition. Whereas the first two are defined (following this article's first conceptual suggestion) mostly according to the spatial reach and depth of their influence, regional powers are defined by their 
relative security context. That is, regional powers only exist as long as there are no (relatively) superior powers within a given complex, regardless of how powerful (in absolute terms) they are.

As such, there is no necessary power continuum between the regional and the great power levels. The tools used to define a regional power (comparative power assessment) are not those that define a global power (individual spatial scope and depth). Thus, in the discontinuity between these two levels, it becomes possible to have a great power insulator. Even though this has not recently happened in practice, it is perfectly conceivable in theory that an insulator increases its material conditions and develops a more active presence on the international stage without necessarily having to belong to any RSC.

In short, by first attaching the concept of great power to the scope and depth of a state's potential (multi)regional security impact (rather than the mere combination of capabilities and peer perception) and then detaching those same great powers from the relative regional power condition, it becomes possible to have great powers that do not necessarily have a regional power status. That is, it becomes possible to acknowledge the potential existence of great power insulators. This idea opens up the possibility of understanding Turkey's ascendancy in the international system without having to constantly assess whether Ankara is becoming a European or a Middle Eastern power. But can Turkey already be defined as a great power? And to what extent can a great power insulator behave as if it were indifferent to its regionless condition? These are the two questions that will cut across the second part of this article.

\section{Turkey and Regional Security Complex Theory}

As acknowledged by Buzan and Wæver, Turkey is a special kind of insulator. Whereas insulators usually play a passive role, Turkey is very active in the RSCs that surround it. Still, as the authors recognize, 'Turkey is not able to bring the different RSCs together, to make them form one coherent strategic arena, of which it is part' (Buzan \& Wæver 2003: 485).

With few exceptions, since the inception of the Turkish Republic in 1923, the country has followed Mustafa Kemal Atatürk's principle of 'peace at home, peace abroad' (quoted in Kazan, 2005: 591), focusing on the fulfilment of common goals and policies with neighbouring countries that do not compromise Turkey's independence or sovereignty. Indeed, after the disaster of World War I, Turkey embarked on a thorough domestic nation-building project, leaving little time or interest to explore in-depth relations with other countries. As a consequence, it was able to sit at the margins of World War II, declaring its neutrality in the conflict (see Kösebalaban, 2011).

The post-1945 bipolarization of the international system combined with improved relations with the United States resulted in Turkey aligning its international security concerns with the North Atlantic Treaty Organization (NATO). However, despite institutional arrangements, Turkey's security relations with the US-dominated European space were largely limited to its (difficult) relations with Greece and 
Cyprus (see Nachmani, 2002). In that sense, Turkey's membership of this organization had a mostly symbolic importance in Turkish domestic politics, as it passed on the image of Turkey's closeness to Europe, as envisioned by Atatürk. In security terms, however (and that is what ultimately matters when discussing $\mathrm{RSCs}^{6}$ ), NATO's membership did not lead to a more active presence on the international stage. It merely institutionalized Turkey's alliance with the US while officially defining the Soviet Union (USSR) as Turkey's major security concern.

The dissolution of the Soviet bloc, combined with President Turgut Özal's neoOttomanism in the early 1990 s $^{7}$ led to Turkey resuming relations with regions that were culturally close but had been under the influence of the Soviet bloc during the previous decades, namely the Balkans, Caucasus and Central Asia (Aras \& Gorener, 2010: 80). It also developed a more active presence in the Middle East, first with the Gulf War and the influx of refugees from northern Iraq (which had important repercussions on its conflict with Kurdish insurgents in the south-eastern part of its territory), then with Israel in the mid-1990s and finally with Syria, which Turkey threatened to invade in 1998 if Damascus did not hand over Abdullah Öcalan, the leader of the Kurdistan Workers' Party (PKK). ${ }^{8}$

With the end of the Cold War and the consequent loss of strategic interest in Turkey spearheading the Atlantic Alliance in south-eastern Europe, the country was increasingly perceived, in the political discourse of its western allies, as a bridge between the western world and the strategically important Middle East and Central Asia. However, as illuminated by RSCT, Turkey was more of a gap than a bridge as it was not sufficiently involved in any RSC to act as an intermediary. In the Middle East, its ambivalent behaviour during the Iraq-Iran war, and its secondary role in the Palestine-Israel conflict, were proof that its security concerns, with the exception of the Kurdish issue, had little to do with those of the region. The major exception was Israel, with which Turkey developed close ties (see Inbar, 2002), particularly in the field of defence, culminating in the signing of multiple military agreements between 1996 and 1998 (Yavuz, 2010). Not even in the Balkans, an area of particular strategic interest and cultural proximity, did Turkey have a particularly central role during the Bosnia and Kosovo conflicts. In short, despite the changes induced in the country's foreign and security policy after the end of the Cold War, for Buzan and Wæver (2003: 395), Turkey was still an insulator in late 2002, as it could not create a coherent strategic arena involving its surrounding RSCs.

\section{The AKP and the Redefinition of Turkey's Foreign and Security Policy}

The November 2002 general elections were an important milestone in Turkey's recent history. The AKP's electoral victory meant that, for the first time in many decades, one party managed to acquire a clear majority in the Turkish Parliament. It also signified the return to power of a significant number of politicians that had previously belonged to the outlawed Islamic-oriented Refah party, including its leaders Abdullah Gül and Recep Tayyip Erdoğan. The AKP mixed a modernist discourse with a conservative social view of the world, 'akin to Europe's Christian 
Democrats' (Baran, 2010: 47), that convinced an important portion of the country's electorate.

Externally, Turkey's previous experience with a party with Islamic roots, Necmettin Erbakan's above-mentioned Refah party, had led to a disastrous shortlived foreign policy that attempted to refocus on cultural proximity with the Muslim world. Among other things, Erbakan had proposed the creation of a Muslim NATO and adopted an ambiguous position on the Kurdish issue, which ultimately led to its indirect removal from power by the military in 1997. Thus, there were some doubts about Turkey's strategic direction with an AKP government at the helm. Those doubts rapidly dissipated as Turkey maintained the foreign and security policy priorities set by previous governments, clearly focusing on the EU accession process, which reached its high point in October 2005 when Turkey started accession negotiations with Brussels. In addition, the AKP continued Turkey's cooperation with the International Monetary Fund (IMF) and highlighted the centrality of NATO, the US and Israel in guaranteeing Turkey's international security (Baran, 2010: 47).

However, this was to change as Turkey's relations with the EU deteriorated, while its economy expanded, providing the material conditions for the country to diversify its foreign and security relations, enhancing ties with the Middle East, Central Asia and the Black Sea region. Recep Tayyip Erdoğan's foreign policy advisor, Ahmet Davutoğlu, was particularly responsible for this change of priorities in Turkey's foreign relations. In 2001, this International Relations professor published a monograph entitled Strategic Depth (Stratejik Derinlik), which argued for the repositioning of Turkey 'from the periphery of international relations to the center as an actor sitting at the intersection of multiple regions' (Kirişçi et al., 2010: 12). Such a strategy became, to a large extent, the blueprint for the AKP's foreign policy. ${ }^{9}$

The 2007-08 political crisis (see Patton, 2007: 351) in Turkey led to the further reinforcement of the AKP's position within the Turkish political system, first with the re-election of Recep Tayyip Erdoğan, and then with the nomination of foreign minister Abdullah Gül as president of Turkey. As a consequence, Ahmet Davutoğlu was appointed to the post of minister of foreign affairs. He could now directly implement his vision for Turkey's foreign and security policy.

For Davutoğlu (2008), Turkey's international behaviour should reflect both its history and geography, that is, both its positioning at the junction of different regions and its rich past (Bilgin, 2009: 120), from being the centre of the Ottoman Empire to a full-fledged NATO member (Barysch, 2010: 4). As he put it, 'Turkey's national interest lies in the proper utilization of its geography' (Davutoğlu, 2008: 92). Turkey's geopolitical positioning means its identity cannot be 'reduced to one unified character'; on the contrary, it must be 'defined as a central country with multiple regional identities' (ibid.: 78). In Davutoğlu's view, '[i]n terms of its area of influence, Turkey is a Middle Eastern, Balkan, Caucasian, Central Asian, Caspian, Mediterranean, Gulf, and Black Sea country' (ibid.: 79). In practice, the application of these principles has led Turkey to move 'away from security oriented and zero-sum mentality', emphasizing, instead, a 'constructive engagement' with its neighbours (Altunışık, 2009: 30). 
Security remains central to Turkey in its relations with the Middle East, but under quite different terms. Whereas in previous decades Turkey had opted for a cautious policy towards the region, in which its south-eastern neighbours were understood as potential security threats, it has switched to a desecuritizing agenda since 2002, attempting to mediate a number of different conflicts and stand-offs within its neighbourhood (ibid.: 32). Between 2004 and 2011 Turkey was very active in engaging with Iran, Israel, Syria, Palestine, Lebanon and Jordan, contributing to the resolution of domestic and regional conflicts in which these actors were involved. A good example of this was Turkey's attempt to mediate between Syria and Israel, a process interrupted by Tel Aviv's incursion into Gaza in the winter of 2008-09. Until then, Turkey had made various efforts to bring together all the different parties involved in the conflict. After the invasion, and despite the famous spat between Recep Tayyip Erdoğan and Israel's then foreign minister Shimon Peres, it was still involved in attempting to put an end to Israel's invasion of Gaza (Hurryiet Daily News, 2009). That was eventually accomplished, with Turkey playing a critical role in bringing Israel and Hamas, as well the other key stakeholders in the region, together to agree on a ceasefire, according to foreign minister Ahmet Davutoğlu (Today's Zaman, 2009b).

Turkey's mediation efforts in the Middle East have been accompanied by a much more assertive stance towards Israel (compared to the 1990s). Relations between the countries have considerably worsened in the last few years, reaching their lowest point in the summer of 2010 when a humanitarian flotilla sponsored by Turkey, which aimed to break through the Gaza blockade, was intercepted by the Israel Defence Forces on the high seas. This resulted in the deaths of nine people, eight of whom were Turkish citizens, leading to a significant deterioration in the relations between the two countries (Yavuz, 2010).

Apart from the Israel-Palestine conflict, Turkey has also been closely involved in the Iran nuclear issue. For Turkey, although the idea of having Iran as a nuclear power is far from positive, alienating the Tehran regime is perceived as being even worse. As mentioned by Meliha Altunışık (2009: 32), the 'possible nuclearization of Iran, which may provoke a general proliferation in the region, is not clearly welcomed by Turkey'. In a recent poll conducted by KA Research and the Turkish Economic and Social Studies Foundation (TESEV), 65 per cent of respondents stated their opposition to Iran's military nuclear programme (Today's Zaman, 2011).

In 2009, Turkey's trade volume with Iran was worth $\$ 10 \mathrm{bn}$ and it is expected to triple in the next few years. The two countries have started to cooperate more closely in energy matters, as exemplified by the construction of a natural gas pipeline between Tabriz and Ankara, in operation since 2001. Iran has become Turkey's biggest supplier of natural gas after Russia, with 12 per cent being imported from there (Kiniklioğlu, 2010: 94).

These geopolitical considerations combined with increased economic and energy interests have put Turkey at the centre of this international issue of paramount importance. Recep Tayyip Erdoğan visited Tehran in November 2009, followed by Ahmet Davutoğlu in February 2010. Turkey's foreign minister had the explicit goal of reaching an agreement regarding the transfer of Iran's enriched uranium. This was 
achieved in May with the participation of Brazil, involving the transfer of 1,200 kg of uranium to Turkey (which would still be Iran's property) in exchange for a research reactor. The agreement was promptly rejected by the US, which led to the UN Security Council Resolution to intensify sanctions against Iran. Despite its best efforts, and its association with Brazil, a larger emerging power, it became clear in this case that there was a power hierarchy in the international system and that Turkey, and Brazil, were not part of its top tier.

Outside the Middle East, Turkey has also strengthened its links with Central Asia and the Caucasus region. In the case of the latter, relations with Armenia have somewhat improved, despite on-going tensions regarding the alleged Armenian genocide committed by Ottoman forces in 1915 and the Nagorno-Karabakh conflict between Armenia and Azerbaijan. Turkey has also actively promoted a Black Sea policy that led to the creation of the Black Sea Naval Co-Operation Task Group (BLACKSEAFOR) in 2001, and the setting up of Operation Black Sea Harmony in 2004.

In addition to the intensification of its relations with its neighbours, Turkey has also been establishing trading partnerships with China, India, Russia and Brazil. South America, together with Africa, has seen the opening of dozens of new Turkish embassies in a clear attempt by Ankara to diversify its political and economic ties (Davutoğlu, 2012: 6).

Even though Turkey's revised foreign and security policy has contributed significantly to improving its relations with the Middle East, Central Asia and the Caucasus region, and expanding its links with other emerging countries and regions, the same does not apply to its relations with the European Union and the United States. The EU accession process is not moving forward (see Vaïsse et al., 2012). Half of the negotiation chapters have been blocked by either the EU or specific member states, and Cyprus remains a key obstacle in the negotiations between Ankara and Brussels. That said, Turkey's official discourse maintains EU accession as its most important foreign policy goal. ${ }^{10}$ In the words of state minister Ali Babacan (2010: 21), 'EU accession represents the final stage of Turkey's almost 200-year-old modernization efforts'. In reality, the EU is responsible for 46 per cent of Turkey's exports, as well as for about 88 per cent of its foreign direct investment (IISS, 2010: 3), making it a key partner in the country's recent economic success.

Relations with the US have also undergone some difficult periods, particularly since the Iraq War, when the Turkish Parliament blocked the US's intention of using Turkey's south-eastern border to deploy troops into Iraq. Since then, relations between the two countries have been intermittent at best, with Turkey being highly concerned with the destabilizing consequences of the US invasion of Iraq (particularly regarding the Kurdish region). On the other hand, the US is sceptical of the AKP's foreign policy goals for the Middle East. Washington is particularly concerned that two of its most solid allies in the region - Turkey and Israel - are not able to cooperate, putting at risk its policy for the Middle East. In addition, the apparent improvement in relations between Turkey and Iran is also irritating the United States, which often questions Ankara's commitment to the Atlantic Alliance (The Jerusalem Post, 2010). 
Nonetheless, Turkey remains a very important strategic ally for the US. ${ }^{11}$ For instance, in August 2010, soon after Turkey voted against the US proposal in the UNSC, the undersecretary for the Turkish Foreign Ministry, Feridun Siniloğlu visited William Burns, the US undersecretary for political affairs, in order to ease the tensions between the two countries (Adilgizi, 2010). More recently, Turkey's role during the Arab Spring and the progressive alignment of interest between Ankara and Washington in the Middle East, particularly regarding Syria, together with the good personal relations between the US president and the Turkish prime minister (Albright et al., 2012: 6), have contributed to a more positive relationship between the two countries. Some important symbolic steps were taken in their relationship, such as Turkey's eventual acceptance of a NATO radar system that is part of the missile shield initiative Washington wishes to see implemented in south-eastern Europe. This agreement came only after Ankara received confirmation from its US counterparts that the system was not designed to specifically protect Europe from a potential Iranian attack. It did not, however, receive any assurances regarding information-sharing with Israel, another demand from Ankara that was eventually dropped (Shanker, 2011). More recently, Turkey's request for the installation of Patriot missiles next to the Syrian border was also a strong recognition of the country's positioning as a full-fledged NATO member.

Turkey's concerns with Iran and Israel, while dealing with the US within the context of NATO, is a self-evident scenario of the complexities associated with its security priorities: it wants to maintain stable relations with Iran, continue its diplomatic rift with Israel and contribute to a missile system that is against the interests of the former and is in line with the latter's geopolitical positioning.

In addition to NATO, Turkey has also been active in different multilateral fora, such as the United Nations, where it has held a non-permanent position in the Security Council, or in the Organization of the Islamic Conference (OIC), where it lobbied very strongly to have academic and diplomat Ekmelledin Ihasonoğlu as the organization's secretary-general (2004-12). Turkey has also been an active promoter of new international institutions. In 2007, together with Spain, it promoted the Alliance of Civilizations, an institution concerned with the promotion of cultural exchange. One year later, in the follow-up to the Georgian crisis, it proposed the creation of a Platform for Stability and Cooperation in the Caucasus, which was eventually established in that same year, though there has been little progress since due to Russia's lack of interest in the project. In September 2010, Ankara also launched a Turkic-Speaking Countries Cooperation Council, consisting mostly of Central Asian countries, which aimed at promoting solidarity and cooperation among its participants (Adilgizi, 2010). The intensive use of multilateral mechanisms is part of Turkey's strategy of balancing bilateralism and multilateralism in an attempt to diversify its foreign policy channels (Onar, 2009: 11-12). This can be seen in Turkey's involvement in the reforms, conflicts and revolutions that have taken place in the Middle East and North Africa (MENA) region since 2011, when it addition to its bilateral relations, it has, depending on the issue, 
worked closely with the Arab League, the Gulf Cooperation Council, the UN and NATO. The results have been mixed, to say the least.

\section{The Arab Spring Test}

As mentioned above, Turkey has since the mid-2000s adopted a proactive, mediating role in the Middle East. Despite some minor successes, its efforts have been questioned, first by its deteriorating relations with Israel, and then by its active involvement in the 2011-12 Arab world uprisings. These have often forced Turkey to take sides, enmeshing it in regional power games of great complexity, particularly difficult to manage from an insulator position.

The Tunisian case was not particularly challenging for Turkey given its limited relationship with Ben Ali's regime. Libya, Syria and Egypt have, however, been more difficult cases to handle. In Libya, it was clear that Turkey was having difficulty in reconciling an aggressive economic policy with an active diplomacy that avoided interfering in the internal affairs of other states. The 20,000 Turkish workers who were living in Libya, combined with the \$15bn worth of projects that the Qadhafi regime granted to Turkish companies, contributed to Turkey's initially conservative stance towards the turmoil in that country. Ankara even attempted to work as mediator between Tripoli and the rebels. That position changed with time, as it was becoming clearer that Qadhafi was going to be toppled sooner or later. Ahmet Davutoğlu's visit to Benghazi, still during the civil war, and Turkey's donation of \$200m to the National Transitional Council were signs of this (Kardaş, 2011).

Regarding Egypt, Turkey was more assertive, with Recep Tayyip Erdoğan being the first international leader to call for Mubarak's resignation. The pace of the events on the ground and the lack of particularly good relations with Egypt's former president facilitated the adoption of this position. Finally, in the on-going Syrian revolt, Turkey has been forced by events to take a stance that largely undermined the diplomatic relations between Ankara and Damascus. Turkey tried to benefit from its proximity to the Syrian regime - 'Turkey's biggest diplomatic investment in recent years' (Phillips, 2012:2) - to convince it to change track and undertake structural reforms that could meet the protesters' demands during the initial stages of the revolt (Oğuzlu, 2012: 6). The fact that Bashar Al-Assad did not heed Turkey's demands showed its limits in terms of influencing the security of the region. The ambivalent reactions to Ankara's support for the Syrian armed opposition, and the less-thanclear articulation with both Qatar and Saudi Arabia (which is somewhat sceptical of Turkey's involvement in the region) regarding that support (see Phillips, 2012) have further contributed to the general feeling that Turkey has conflicting interests in the Middle East that derive precisely from its insulator position, which obliges it to play on diverse chessboards simultaneously, while always doing so as a guest in someone else's region.

The Arab Spring has revealed all the contradictions that Turkey's diplomacy faces. On the one hand, it shows its NATO allies that it can have an independent (or at least autonomous) foreign policy, often co-ordinating its actions with the Arab League and the Gulf Cooperation Council. On the other hand, it is still seen by its 
Arab neighbours as part of that Western Alliance and needs the support of the Alliance when dealing with Syria. It also tries to be a moderator in the region, without being able to avoid taking sides and while assuming an aggressive stance towards countries such as Israel or Syria (Cornell, 2012: 16). Finally, it has tried to promote a status quo policy that guarantees the region's stability, while supporting rebel movements in countries such as in Libya and Syria.

In a post-Arab Spring assessment of Turkey's role in the region, Ahmet Davutoğlu rejects any incompatibility between Turkey's simultaneous push for both democracy and stability. In his view 'there is no contradiction between our [Turkey's] emphasis on democratic demands, which in some cases required us to confront repressive regimes, and our foreign policy principle of zero problems with neighbors' (Davutoğlu, 2012: 8). Practice, however, shows that such a balance is often difficult to establish, and supporting 'the demands of the Arab people wherever they are, and whatever the content of their demands are' (ibid.) eventually leads one to pick sides, and accept the inevitability of confronting those who stand on the opposite side of the barricades. Despite all the hype surrounding the 'Turkish model' as a potential follow-up model for countries such as Tunisia and Egypt (see Kirişçi, 2011), Turkey is still seen as an outsider, limited by its insulator condition.

\section{Is Turkey a Great Power?}

As mentioned before, it was not without effort that Turkey was made to fit the insulator concept, as the problem overspilled the conceptual box to which it had been allocated. It could be argued that Turkey is too active and too big to remain in such a position for much longer. Turkey is becoming or at least acting as a global power in the making.

It is an important political, economic and military actor in all its surrounding security complexes - Europe, Middle East and former Soviet Space - as well as in most of their sub-complexes - the Balkans, Levant, Gulf, Maghreb, Caucasus and Central Asia. Politically speaking, Turkey's bilateral and multilateral policies, as seen before, indicate a clear preference for a further intensification and diversification of its international relations. Therefore, it is quite possible that the scope and depth of Turkey's multi-regional engagement will be enhanced in the coming decades, also fuelled by its impressive economic growth (see Albright et al., 2012). In 2002 Turkey's exports equalled a total of \$36bn. Six years later, they had reached $\$ 132 \mathrm{bn}$, making Turkey's economy the 16th biggest in the world and the 6th largest in Europe (Kiniklioğlu, 2010: 94). According to Goldman Sachs, at this pace, Turkey will be the ninth largest economy in the world by 2050 (Marthoz, 2010: 11). These are impressive figures in the context of Turkey's recent past, though less so compared to other emerging powers.

Although, as argued before, a great power should predominantly be measured against its absolute (rather than relative) impact, it is important to compare the performance of different global powers, in order to (a) understand possible power discrepancies at global level and (b) be able to more accurately assess the evolution of a great powers' trajectory: a state with a declining economy or a consecutive 
disinvestment in defence will most likely tend towards a less significative position in the international field and vice versa.

In that sense, Turkey's economic (above) and military capabilities (below) still lag substantially behind all the currently identified international powers. A quick comparison with five other emerging powers ${ }^{12}$ shows that despite its economic growth and military might (IISS, 2011), it still lags behind countries such as India, Brazil, Russia, China or Japan. In relation to those major international powers, Turkey's defence expenditure in absolute terms is bigger only than Brazil's, which has a smaller budget than other South American countries, such as Venezuela, Colombia and Chile (Soares \& Hirst, 2006: 38). Such economic and military constraints do impede Turkey from becoming a full-fledged great power, as acknowledged by its foreign minister Ahmet Davutoğlu, for whom Turkey is currently in an intermediate position - it is a 'supra-regional power' with 'global power' ambitions (quoted in Kardaş, 2010: 128).

In short, it could be argued that, historically, RSCT has accurately portrayed Turkey's positioning in the international security realm as one marked by its insulator condition. The theory is clear and coherent, and does not necessarily follow the common-sense logic of interpreting Turkey as a European or Middle Eastern power. In addition, it offers a very useful framework for understanding issues such as Turkey's incapacity to successfully deal with the Middle Eastern dimension of the Kurdish issue, or the absence of a particularly active role in the Balkans during the 1990s. The fact that Turkey does not belong to any particular RSC, although sharing many cultural and geopolitical ties with most of its neighbours, inadvertently puts it in a favourable position to fulfil that role in its immediate neighbourhood. As we have seen, this has only been possible by a shift in Turkey's self-assessment regarding the security dynamics that surround it. Rather than trying to avoid them, and limit its activity to the issues that directly affect its national security, it has changed to a pro-active policy that attempts to turn obstacles into opportunities. This is particularly evident in the economic realm, where its economic growth has directly translated into the development of much stronger commercial ties with its neighbourhood. ${ }^{13}$

The key point here is that Ankara's improved ties not only with its Middle Eastern neighbours but also with the Balkans, Black Sea, Central Asia and other regions such as Africa and South America (with which it had had limited contact until recently) are all related to a clear foreign and security policy designed to transform Turkey into a great power in the international system within the next decade.

\section{Conclusion}

Turkey has changed quite significantly since Regions and Powers was published in 2003. It is now extremely active in its neighbourhood(s), through 'deepening political dialogue with its neighbours; increasing its trade and energy relations with them; and encouraging direct people-to-people contact with them' (Kiniklioğlu, 2010: 94). It has also moved from a security perception based on enmity relations with its neighbours to one, if not of amity, at least of stronger convergence of 
interests (see Kösebalaban, 2011). All this has been wrapped in an increasingly affirmative discourse of leadership and power. Recep Tayyip Erdoğan himself confirmed this when he declared, after winning the 2011 general elections, that his victory would be beneficial not only for Turkey but also for the 'friendly and brotherly nations from Baghdad, Damascus, Beirut, Amman, Cairo, Sarajevo, Baku and Nicosia' (quoted in Cornell, 2012: 13).

Those changes in Turkey's foreign and security policy have been accompanied by a significant increase in its material capabilities - particularly its economy - as well by its peers' recognition of its increasing importance in the international scene. Turkey's political leadership recognizes that Turkey is still a great power project rather than a reality.

As has already been suggested, RSCT is ill-equipped to deal with Turkey's international ambitions due to the self-imposition of unnecessary conceptual obstacles. By clearly establishing that a great power must have previously been a regional power, Buzan and Wrver render it impossible for an insulator state to become an international power. However, according to the definition of great powers presented by these authors, there is nothing that rejects such an idea. Thus, this article has argued that, by disconnecting the concepts of regional and great powers, it is possible to have a great power insulator. The question then is: how is this relevant to understanding Turkey's foreign and security dynamics? Very relevant, this article would argue. If Turkey has the ambition of becoming a great power, then RSCT, if unchanged, would be unable to explain those dynamics. The analysis would always be limited to the possibility of Turkey becoming or not being part of a given RSC. Questions related to Turkey's emergence in the international system would have to be left unanswered as the case would present an anomaly that the theory in itself would not be able to explain. This would be unfortunate given RSCT's potential to reveal security dynamics that seem absent from a commonsense analysis of Turkey's position within its regional security environment, such as explaining the consequences for Turkey of not belonging to any particular RSC.

Even if it is arguably difficult to maintain that Turkey is still an insulator, it is not particularly easy to insert it into one exclusive RSC. This means that, irrespective of its international power status, Turkey operates in a regional environment that is not entirely unfamiliar - politically, culturally and economically - but to which it does not fully belong. As a consequence, it does not enjoy the advantage that all other current great powers have of having a regional basis from which to operate: it does not have its own 'backyard'. Even if Turkey rises to the top ten of world economies and acquires an even stronger voice on international security issues, this should be kept in mind. As mentioned by Işil Kazan (2005: 590), 'being an insulator is not an easy position, because an insulator has to absorb the different security dynamics that it is surrounded by'. The tentative reversal of this process - to influence, rather than to absorb - might drag the insulator state into security dynamics to which it does not belong. That same risk is present in a great power that does not belong to any RSC, as the logic of being engulfed in external security is still there, though it is in a more active position. As a consequence, any great power that occupies an insulator position will have a more limited margin of manoeuvre when compared with a great 
power placed in a RSC. Without a firm spatial basis, a great power is always acting on foreign RSCs, an activity that can be tiresome and prone to political miscalculations and overstretching, as Turkey's involvement in the Arab Spring often revealed. The possibility of being downgraded to an insulator position is thus high. The precarious spatial condition in which a former insulator operates makes it more difficult to sustain a great power position in the long term.

Secondly, this geopolitical fragility makes it easier for Turkey to overextend its foreign policy (Altunış1k, 2009: 37), as it sees itself involved simultaneously in different security dynamics that it does not fully control. Hence, it runs the constant risk of 'dangerously overreaching' (Abramowitz \& Barkey, 2009: 127), ultimately jeopardizing its long-term term strategy. In the last few years, there have already been some examples of this, such as when Turkey's attempt to improve relations with Armenia challenged the status quo in the Caucasus, putting under additional strain Ankara's relations with oil-rich Baku; or when it decided to take a stronger stance on the Israeli-Palestinian conflict, at the expense of its relations with the country that was, until recently, its most important interlocutor in the region, Israel.

These two examples illustrate the difficulties Turkey has had in sitting at the intersection of different RSCs without fully belonging to any of them. By re-defining the criteria from which to consider the existence of an international power (be it super or great) and by breaking the evolutionary link between insulators, regional powers and great powers, it is possible to give RSCT the necessary conceptual tools to retain the explanatory pertinence that help explain the rise (and the challenges) of emerging powers such as Turkey.

\section{Notes}

1 Throughout this article the term 'foreign and security policy' will be used instead of just 'foreign policy' as Regional Security Complex Theory analyses international security and not international relations at large. This is the prism through which RSCT views the world, and so this article follows suit. In that sense, it is necessary to understand that Turkey's external actions are part not only of its foreign policy but also of its security policy, even when those actions are not directly concerned with security.

2 A good example of this is the number of countries visited by the main Turkish political leaders in the space of 12 months. Following Ufuk Ulutaş (2010: 2), in 2009 President Abdullah Gül visited 29 countries, prime minister Erdoğan 23 and the minister of foreign affairs (Ali Babacan in the first half of 2009 and Ahmet Davutoğlu from thereafter) 93.

3 According to the European Foreign Policy Scorecard, 2012 'was another lost year for the EU and Turkey' (Vaïsse 2012: 78).

4 In this typology, the concept of 'great power' as used by authors such as John Mearsheimer (2001) and Andrew Hurrell (2006) is replaced by the term 'superpower'.

5 As defined by Buzan and Wæver (2003: 50), 'RSCs are durable rather than permanent patterns'.

${ }^{6}$ According to Buzan and Wæver (2003: 76), RSCT 'is a reading of the world political development through the perspective of security'.

7 Turgut Özal's foreign policy was indeed 'a major break' (Kirişçi et al., 2010: 19) from the traditional Ankara's international behaviour, focusing on extending economic and commercial ties as a source of reducing tensions in its neighbourhood (ibid.).

8 The al-Assad regime would eventually expel the PKK leader, who then embarked on a Europe-wide tour, trying to find a country which would grant him political asylum. He would finally be arrested in February 1999 at the Greek embassy in Nairobi. 
9 According to the AKP deputy chairman of external affairs and member of the Turkish Parliament Suat Kiniklioğlu (2010: 93), 'Turkey's neighbourhood policy ... is a direct outcome of the "Strategic Depth" concept articulated by Turkey’s Foreign Minister Ahmet Davutoğlu'.

10 According to the above-mentioned study conducted by KA Research and the Turkish Economic and Social Studies Foundation (TESEV), 69 per cent of the respondents were in favour of Turkish accession (Today's Zaman, 2011).

11 About 70 per cent of goods and equipment sent to Iraq travel through the US military base in Incirlik (Larrabee, 2009: 99).

12 China, Russia, Brazil, India and Japan.

13 In 2000, Turkey exported to its 11 closest neighbours \$2.7bn. Eight years later, that number had risen to \$28bn (Kiniklioğlu, 2010: 94).

\section{References}

Abramowitz, M. \& Barkey, H. J. (2009) Turkey's transformation. The AKP sees big, Foreign Affairs, 88(6), pp. $118-128$.

Adilgizi, L. (2010) Turkish globe, Turkish Review, 1(1), pp. 10-11.

Albright, M. K., Hadley, S. J. \& Cook, S. A. (2012) U.S.-Turkey relations, A new partnership, Independent Task Force Report No. 69, Council on Foreign Relations, Available at http://www.cfr. org/turkey/us-turkey-relations/p28139 (accessed 2 August 2012).

Altunışık, M. (2009) Turkey's new activism in the Middle East, Negócios Estrangeiros, 14, pp. 29-39.

Aras, B. \& Gorener, A. (2010) National role conceptions and foreign policy orientation: the ideational bases of the Justice and Development Party's foreign policy activism in the Middle East, Journal of Balkan and Near Eastern Studies, 12(1), pp. 73-92.

Babacan, A. (2010) Living in difficult times, Turkish Review, 1(1), pp. 16-20.

Baran, Z. (2010) The rise of political Islam and the AKP, in: Z. Baran (Ed.) Torn Country: Turkey between Secularism and Islamism (Stanford, CA: Hoover Institute Press), pp. 29-51.

Barysch, K. (2010) Can Turkey combine EU accession and regional leadership? Policy Brief, Center for European Reform.

Bilgin, P. (2009) Securing Turkey through western-oriented foreign policy, New Perspectives on Turkey, 40, pp. $105-125$.

Buzan B., Wæver, O. (2003) Regions and Powers. The Structure of International Security (Cambridge: Cambridge University Press).

Cornell, S. (2012) What drives Turkish foreign policy? Middle East Quarterly, (Winter), pp. 13-24.

Davutoğlu, A. (2008) Turkey's foreign policy vision: an assessment of 2007, Insight Turkey, 10(1), pp. $77-97$.

Davutoğlu, A. (2012) Principles of Turkish foreign policy and regional political structuring, SAM Vision Papers No. 3, April 2012.

Diez, T. (2005) Turkey, the European Union and security complexes revisited, Mediterranean Politics, 10(2), pp. 167-180.

Hurrell, A. (2006) Hegemony, liberalism and global order: what space for would-be great powers? International Affairs, 82(1), pp. 1-19.

Hurriyet Daily News (2009) Turkey ready for monitoring mission on Gaza-government official, 15 January.

IISS (2010) Turkey's bid to raise influence in Middle East, Strategic Comments, 16(8), pp. 1-3.

IISS (2011) Chapter ten: country comparisons - commitments, force levels and economics, The Military Balance, 111(1), pp. 451-482.

Inbar, E. (2002) The strategic glue in the Israeli-Turkish alignment, in: Barry Rubin \& Kemal Kirişçi (Eds) Turkey in World Politics. An Emerging Multiregional Power (Istanbul: Boğaziçi University Press), pp. 151-168.

Kardaş, S. (2010) Turkey: redrawing the Middle East map or building sandcastles? Middle East Policy, XVII(1), pp. 115-136. 
Kardaş, S. (2011) Turkey and the Arab Spring: coming to terms with democracy promotion? Policy Brief, The German Marshall Fund of the United States, October.

Kazan, I. (2003) Regionalisation of Security and Securitisation of a Region (Copenhagen: University of Copenhagen Press).

Kazan, I. (2005) Turkey: where geopolitics still matters, Contemporary Security Policy, 26(3), pp. 588-604.

Kiniklioğlu, S. (2010) Turkey's Neighbourhood and Beyond: Tectonic Transformation at Work? The International Spectator, 45(4), pp. 93-100.

Kirişçi, K. (2011) Turkey's 'demonstrative effect' and the transformation of the Middle East, Insight Turkey, 13(2), pp. 33-55.

Kirişçi, K., Tocci, N. \& Walker, J. (2010) A neighborhood rediscovered. Turkey's transatlantic value in the Middle East, in: Brussels Forum Paper Series (Washington, DC: The German Marshall Fund of the United States).

Kösebalaban, H. (2011) Turkish Foreign Policy. Islam, Nationalism and Globalization (New York: Palgrave Macmillan).

Larrabee, S. (2009) Revitalizar las relaciones con Estados Unidos, Vanguardia Dossier, No. 32.

Marthoz, J. (2010) Turkey turns the tide, The Broker, No. 24, pp. 10-13.

Mearsheimer, J. (2001) The Tragedy of Great Power Politics (New York: Norton).

Nachmani, A. (2002) What says the neighbor to the West? On Turkish-Greek relations, in: Barry Rubin \& Kemal Kiriş̧̧i (Eds) Turkey in World Politics. An Emerging Multiregional Power (Istanbul: Bogazici University Press), pp. 93-122.

Onar, N. F. (2009) Neo Ottomanism, historical legacies and Turkish foreign policy, EDAM Discussion Paper Series, 3.

Oğuzlu, T. (2012) The 'Arab Spring' and the rise of the 2-0 version of Turkey's 'zero problems with neighbors' policy, SAM Papers No. 1.

Patton, M. J. (2007) AKP reform fatigue in Turkey: what has happened to the EU process? Mediterranean Politics, 12(3), pp. 339-358.

Phillips, C. (2012) Into the quagmire: Turkey's frustrated Syria policy, Briefing Paper (December), Chatham House.

Shanker, T. (2011) U.S. hails deal with Turkey on missile shield, The New York Times, 15 September

Soares, M. R. \& Hirst, M. (2006) Brazil as an intermediate state and regional power: action, choice, and responsibilities, International Affairs, 82(1), pp. 21-40.

The Economist (2012) Istanbuls and bears, 7 April.

The Economist (2009) Dreams from their fathers, 23 June.

The Jerusalem Post (2010) US: Turkey must show commitment, 26 June.

Today's Zaman (2011) 69 percent of Turkish public supports EU membership, survey finds, 1 June.

Today's Zaman (2009a) Clinton calls Turkey 'emerging global power' in foreign policy address, 17 July.

Today's Zaman (2009b) Davutoğlu says Turkey key to convincing Hamas on Gaza cease-fire, 20 January.

Ulutaş, U. (2010) Turkish foreign policy in 2009: a year of pro-activity, Insight Turkey, 12(1), pp. 1-12.

Vaïsse, J., et al. (2012) European Foreign Policy Scorecard 2012 (London: ECFR), Available at http:// www.ecfr.eu/content/entry/european_foreign_policy_scorecard_2012 (accessed 29 June 2012).

Yavuz, E. (2010) Turkey to cancel defense agreements with Israel after flotilla attack, Today's Zaman, 8 June.

Yilmaz, M. (2010) Conceptual framework of Turkish foreign policy in the AK Party era, Turkish Review, $1(1)$, pp. $68-73$.

Zaman, A. (2006) Turkey allows Hamas visit, LA Times, 17 February. 